\title{
Evaluation of Liquidity Risk of Commercial Banks
}

\author{
Yueying Liu* \\ Shandong University of Finance and Economics \\ Jinan, Shandong, China \\ 438859229@qq.com
}

\begin{abstract}
In order to understand the current situation of liquidity risk of commercial banks in China, this paper selects the corresponding indicators and uses principal component analysis to comprehensively evaluate the liquidity risk levels of 22 commercial banks in 2017. The results show that Chang Shu Bank, China Construction Bank and Ning Bo Bank have experienced excessive risks; Ping An Bank and Wu Jiang Bank have higher liquidity risks and may deteriorate and need to be prevented. The liquidity risks of the remaining 17 banks are stable. In the research of risk management of commercial banks, few scholars have paid attention to liquidity risk in the past. This paper makes up for this deficiency.
\end{abstract}

Keywords-commercial banks; liquidity risk; principal component analysis; risk management

\section{INTRODUCTION}

The bank risks involved in the "New Capital Accord” cover many aspects such as credit, market, operation, and liquidity risk. For banks, the core risk is liquidity risk. As one of the "three characteristics" of commercial bank operations, liquidity can not only ensure the safety of commercial banks, but also enable banks to earn profits steadily. At present, the liquidity risk is generally defined internationally as: the risk caused by commercial banks not being able to raise the required funds at a reasonable cost in time to fulfill their financial obligations and meet the needs of customers.

As the liquidity risks of domestic and foreign commercial banks continue to intensify, various financial departments are gradually improving the regulatory measures for bank liquidity risks. In 2004, the China Banking Regulatory Commission incorporated the liquidity status into the commercial bank risk management system, emphasizing the management of liquidity risk. In 2013, the Basel Committee on Banking Supervision officially added two liquidity regulatory indicators for commercial banks in Basel III: Liquidity Coverage (LCR) and Net Stable Financing Ratio (NSFR).In 2014, the China Banking Regulatory Commission promulgated the "Measures for the Management of Liquidity Risks of Commercial Banks (Trial)”, which improved and enriched the management mechanism of liquidity risk of commercial banks in China. The Banking Regulatory Commission officially promulgated the "Measures for the Management of Liquidity Risks of Commercial Banks", which will take effect on July 1, 2018. The main contents of this revision include: First, the introduction of three new quantitative indicators: the proportion of net stable funds; high-quality liquidity asset adequacy ratio; liquidity matching rate. The second is to further improve the liquidity risk monitoring system. The third is to refine the requirements related to liquidity risk management.

In order to understand the current situation of the liquidity risk of Chinese commercial banks, this paper draws on 13 liquidity supervision indicators based on previous scholars' research, using principal component analysis method for the 2017 listed commercial banks in 2017. The level of liquidity risk was comprehensively evaluated.

\section{LITERATURE REVIEW}

Domestic and foreign scholars' research on the liquidity risk of commercial banks mainly focuses on two aspects: First, the theoretical analysis of the causes, influencing factors and management schemes of liquidity risks. The second is to conduct an empirical analysis of the liquidity of commercial banks.In terms of theoretical analysis, there are some representative ones: Peter S. Rose (1996) details three methods for measuring liquidity risk: capital structure method, liquidity gap method, and liquidity index method[1]. Oriol Aspachsetal. (2005) argues that in the event of a liquidity crisis, banks will have a smaller liquidity buffer if the central bank gives greater potential support[2]. Ronnie Sadka (2006) argues that information asymmetry can lead to liquidity risk[3]. Nicolae and Lasse HP (2007) argue that strict risk management reduces the size and liquidity of assets held by institutions; while lower liquidity strengthens regulatory oversight[4]. Wu Qiong (2009) believes that in order to deal with liquidity risks, banks need to make structural adjustments to assets and liabilities, and establish a sound liquidity risk early warning mechanism[5]. Fu Qiang (2013) believes that liquidity risk mainly comes from two aspects: one is the uncertainty of the source of funds, and the other is the uncertainty of the use of funds[6].

In empirical research, many scholars have adopted different methods to analyze liquidity risk: Garbade (1979) proposed a method for measuring liquidity risk using variance[7]. Liu Xiaoxing (2010) used Copula-EVT and high-order ES measures to find that the liquidity gap of commercial banks does not obey the normal distribution[8]. Zhong Yonghong (2013) used factor analysis to construct a comprehensive evaluation model for liquidity risk of commercial banks[9]. Shen Peilong and Wang Xiaoting (2013) constructed a stochastic current ratio model and measured the liquidity risk distance and risk probability of 12 listed banks in China[10]. Hu Fangqi (2016) established the GARCH-LaVaR model to analyze the market liquidity risk of listed commercial banks in China [11]. 


\section{MODEL INTRODUCTION AND INDICATOR SELECTION}

\section{A. Principle of principal component analysis}

The basic idea of principal component analysis is to re-integrate a plurality of closely related variables into a set of new and uncorrelated new indicators through orthogonal transformation to replace the original variables.

Suppose there are $\mathrm{n}$ samples, each sample has a total of $\mathrm{p}$ variables, forming a matrix of order:

$$
\mathrm{X}=\left[\begin{array}{ccc}
\mathrm{X}_{11} & \cdots & \mathrm{x}_{1 \mathrm{p}} \\
\vdots & \ddots & \vdots \\
\mathrm{x}_{\mathrm{n} 1} & \cdots & \mathrm{x}_{\mathrm{np}}
\end{array}\right] .
$$

Mark the original variable indicator as: $\mathrm{x}_{1}, \mathrm{x}_{2}, \ldots, \mathrm{x}_{\mathrm{p}}$,

The indicator after the dimension reduction processing is: $Z_{1}, Z_{2} \ldots Z_{m(m} \leq$ p)

$\left\{\begin{array}{c}\mathrm{z}_{1}=\mathrm{l}_{11} \mathrm{x}_{1}+\mathrm{l}_{12} \mathrm{x}_{2}+\cdots+\mathrm{l}_{1 \mathrm{p}} \mathrm{x}_{\mathrm{p}} \\ \mathrm{z}_{2}=\mathrm{l}_{21} \mathrm{x}_{1}+\mathrm{l}_{22} \mathrm{x}_{2}+\cdots+\mathrm{l}_{2 \mathrm{p}} \mathrm{x}_{\mathrm{p}} \\ \cdots \cdots \cdots \\ \mathrm{z}_{\mathrm{m}}=\mathrm{l}_{\mathrm{m} 1} \mathrm{x}_{1}+\mathrm{l}_{\mathrm{m} 2} \mathrm{x}_{2}+\cdots+\mathrm{l}_{\mathrm{mp}} \mathrm{x}_{\mathrm{p}} .\end{array}\right.$

The principle for determining the coefficients $l_{i j}$ in the principal component expression is:

$Z_{i}$ and $Z_{j}(i \neq j)$ are not related to each other

$Z_{1}$ is the largest variance of all linear combinations of $\mathrm{x}_{1}, \mathrm{x}_{2}, \ldots, \mathrm{x}_{\mathrm{p}}$, called the first principal component;

$z_{2}$ is the largest variance of all linear combinations of $\mathrm{x}_{1}, \mathrm{x}_{2}, \ldots, \mathrm{x}_{\mathrm{p}}$ not related to $\mathrm{z}_{1}$, called the second principal component;

$\mathrm{z}_{\mathrm{m}}$ is the largest variance of all linear combinations of $\mathrm{x}_{1}, \mathrm{x}_{2}, \ldots, \mathrm{x}_{\mathrm{p}}$ that are not related to $\mathrm{z}_{1}, \mathrm{z}_{2}, \ldots, \mathrm{z}_{\mathrm{m}-1}$, and is called the mth principal component.

\section{B. Screening basis for the number of principal components}

Cumulative variance contribution rate: When the cumulative variance contribution rate of $\mathrm{m}$ principal components reaches a certain value (generally required to be greater than $80 \%$ ), the m principal components can be retained.

\section{Selection of indicators}

Based on the requirements of the liquidity supervision of Chinese commercial banks, based on the previous studies, combined with the actual situation of financial information disclosure of commercial banks in China, a total of 13 evaluation indicators were selected, including: liquidity ratio and excess reserve ratio. , deposit-loan ratio, interbank borrowing net value ratio, non-performing loan ratio, maximum ten customer loan ratio, single largest customer loan ratio, interest rate sensitivity ratio, non-performing loan provision coverage ratio, capital adequacy ratio, core capital adequacy ratio, cost income Ratio, return on capital. In addition, in order to facilitate the main component score, the direction of the economic meaning of each indicator should be consistent. In view of this, we adjust the reverse index positively. Adjust the loan-to-deposit ratio to 1/loan ratio, using 1 minus the non-performing loan ratio, the maximum ten customer loan ratio, and the single largest customer loan ratio.

\section{OutCOME OF PRACTICE}

\section{A. KMO and Bartlett test}

The statistical analysis of SPSS software is used to analyze the liquidity risk of commercial banks. First, before doing the principal component analysis, we must first perform a KMO test and a Bartlett test on the data to verify whether the data is suitable for principal component analysis.

TABLE I. KMO AND BARTLETT TEST

\begin{tabular}{|c|c|c|}
\hline \multicolumn{2}{|c|}{$\begin{array}{l}\text { Kaiser-Meyer-Olkin Measure of Sampling } \\
\text { Adequacy. }\end{array}$} & \multirow{2}{*}{$\begin{array}{c}.548 \\
166.785\end{array}$} \\
\hline \multirow{3}{*}{$\begin{array}{l}\text { Bartlett's Test of } \\
\text { Sphericity }\end{array}$} & Approx. Chi-Square & \\
\hline & $\mathrm{df}$ & 78 \\
\hline & Sig. & .000 \\
\hline
\end{tabular}

It can be seen from the results that $\mathrm{KMO}>0.5$, Bartlett test sig $=0$, indicating that the data is suitable for principal component analysis.

\section{B. Extracting the main component}

According to the empirical results, we have obtained the variance contribution rate of the first five principal components has reached $84.95 \%$, indicating that these five components explain most of the information.

\section{Calculating the comprehensive score}

TABLE II. COMPREHENSIVE SCORE

\begin{tabular}{|c|c|c|c|c|c|c|c|}
\hline Name & $\mathbf{F}$ & name & $\mathbf{F}$ & name & $\mathbf{F}$ & name & $\mathbf{F}$ \\
\hline ICBC & 0.36747 & $\begin{array}{c}\text { Gui } \\
\text { Yang } \\
\text { Bank }\end{array}$ & 0.195802 & \begin{tabular}{|c|} 
Ning \\
Bo \\
Bank
\end{tabular} & 1.086567 & $\begin{array}{c}\text { Industrial } \\
\text { Bank }\end{array}$ & -0.35777 \\
\hline HSBC & -0.14915 & \begin{tabular}{|c|} 
Min \\
Sheng \\
Bank \\
\end{tabular} & -0.41339 & \begin{tabular}{|c|} 
Ping \\
An \\
Bank \\
\end{tabular} & -0.75435 & \begin{tabular}{|c|} 
China \\
Merchants \\
Bank
\end{tabular} & 0.375469 \\
\hline $\begin{array}{c}\text { Jiang Su } \\
\text { Bank }\end{array}$ & -0.18979 & CCB & 0.526279 & \begin{tabular}{|c|} 
SPD \\
Bank
\end{tabular} & -0.45469 & \begin{tabular}{|c|} 
Zheng \\
Zhou Bank
\end{tabular} & 0.1903 \\
\hline $\begin{array}{c}\text { Bank of } \\
\text { Communications }\end{array}$ & 0.426677 & $\mathrm{ABC}$ & 0.108977 & \begin{tabular}{|c|} 
Shang \\
Hai \\
Bank \\
\end{tabular} & -0.4283 & CITIC & -0.38163 \\
\hline $\begin{array}{l}\text { Bei Jing } \\
\text { Bank }\end{array}$ & -0.38458 & \begin{tabular}{|c|} 
Bank \\
of \\
China
\end{tabular} & 0.159617 & $\begin{array}{c}\text { Wu Xi } \\
\text { Bank }\end{array}$ & -0.20367 & & \\
\hline Chang Shu Bank & 0.556689 & $\begin{array}{l}\text { Nan } \\
\text { Jing } \\
\text { Bank }\end{array}$ & 0.267744 & \begin{tabular}{|c|} 
Wu \\
Jiang \\
Bank \\
\end{tabular} & -0.54428 & & \\
\hline
\end{tabular}

V. RISK DIVISION

\section{A. The " $3 \sigma$ " rule}

This paper uses mathematical statistics to determine the boundary of commercial banks' liquidity risk. According to the error theory, the " $3 \sigma$ " method is proposed to judge the

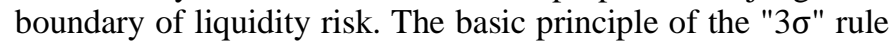
is: according to the principle of normal distribution, the higher 
the distribution probability of the range in which the data is located, the closer the distance from the center value, and vice versa.

In a normal liquidity risk system, the probability that the data is too large or too small from the center value is small. When the data is distributed within the interval: $(\mu-\sigma, \mu+\sigma)$, the bank has no risk; when the data is distributed within the interval: $(\mu+\sigma, \mu+3 \sigma)$, the bank has a little risks; when the data is distributed within the interval: $(\mu-3 \sigma, \mu-\sigma)$, the bank is more risky; when the data is distributed within the interval: $(-\infty, \mu-3 \sigma)$ or $(\mu+3 \sigma,+\infty)$, then the bank has a liquidity crisis.

\section{B. K-S test}

The result is $\operatorname{sig}>0.05$, so it is in compliance with normality. The " $3 \sigma$ " rule can be used. Know by calculation that $\mu=-0.000000168, \sigma=0.455484973475$.

\section{Classification results}

Within the interval $(\mu-\sigma, \mu+\sigma)$, namely $(-0.4554851415$, 0.4554848055), there are ICBC, Hua Xia Bank, Jiang Su Bank, Bank of Communications, Bei Jing Bank, Gui Yang Bank, Min Sheng Bank, ABC, Bank of China, Nan Jing Bank, SPD Bank, Shang Hai Bank, Wu Xi Bank, Industrial Bank, China Merchants Bank, Zheng Zhou Bank, CITIC Bank. It shows that most banks have better liquidity.

Among the intervals $(\mu+\sigma, \mu+3 \sigma)$, namely (0.4554848055, 1.3664547525), there are Chang Shu Bank, CCB and Ning Bo Bank. Explain that these three banks have excess liquidity and have certain risks.

Among the intervals $(\mu-3 \sigma, \mu-\sigma)$, namely (-1.3664550885, -0.4554851415), there are Ping An Bank and Wu Jiang Bank. It shows that most of the indicators of the two banks have deteriorated, showing insufficient liquidity and moderate risks.

\section{CONCLUSION}

In this paper, the principal component analysis and evaluation method is used to comprehensively evaluate and classify the liquidity risk of Chinese commercial banks. The results show that: Generally speaking, the liquidity risk management of Chinese commercial banks is better, and the liquidity risk level of most commercial banks is risk-free region. Chang Shu Bank, China Construction Bank and Ning Bo Bank have experienced risk excesses. There are some risks that need to be observed. However, the liquidity risk level of Ping An Bank and Wu Jiang Bank is high and there is a possibility of deterioration, which needs to be prevented.
The global financial crisis that erupted in 2008 showed that market liquidity conditions could be reversed in the short term and maintained for a long time. In addition, in recent years, a series of domestic and international losses caused by poor liquidity risk management have highlighted the importance and necessity of liquidity risk management for financial market operations and commercial bank management. The management of liquidity risk should not rely solely on the CBRC. Commercial banks should clarify themselves as the main body of liquidity risk management and dominate the liquidity risk management. Commercial banks should establish a reasonable liquidity risk management structure based on their own business strategy, development prospects and business characteristics, combined with the liquidity risk supervision regulations promulgated by the financial regulatory authorities. The state and financial regulatory authorities should also assess the risk efficiency of each bank in a timely manner; so that banks can be effective, and provide timely improvement directions to ensure the sustainable and healthy development of commercial banks and the entire banking system.

\section{REFERENCES}

[1] Rose P S. Implications for future research on bank consolidations in rural markets: Discussion[J]. American Journal of Agricultural Economics, 1996, 78(3):736-737.

[2] Goupil M J , Zahn J P , Zahn J P . Tidal dissipation in binary systems[J]. European Astronomical Society Publications, 2008, 29:67-90.

[3] Sadka R. Momentum and post-earnings-announcement drift anomalies: The role of liquidity risk [J]. Journal of Financial Economics, 2006, 80(2):309-349.

[4] Duffie D, Gârleanu N, Pedersen L H. Valuation in Over-the-Counter Markets[J]. Review of Financial Studies, 2007, 20(6):1865-1900.

[5] Wu Qiong. Liquidity Risks and Countermeasures of China's Commercial Banks[J]. Cooperative Economy and Technology, 2009(2):49-50.In Chinese

[6] FU Qiang, LIU Xing, JI Fang. Evaluation of Liquidity Risk of Commercial Banks[J]. Financial Forum, 2013(4): 9-16.In Chinese

[7] Garbade K D, Silber W L. Structural Organization of Secondary Markets: Clearing Frequency, Dealer Activity and Liquidity Risk[J]. Journal of Finance, 1979, 34(3):577-593.

[8] Liu Xiaoxing, Wang Jinding. Research on Liquidity Risk of Commercial Banks in China-Based on Copula and High-Order ES Measurement[J]. Journal of Guangdong University of Finance and Economics, 2010, 25(5): 26-33.In Chinese

[9] Zhong Yonghong, Cao Danrui. Comprehensive Evaluation of Liquidity Risk of China's Listed Banks[J]. Financial Forum, 2013(1): 15-19.In Chinese

[10] Shen Peilong, Wang Xiaoting. Bank Liquidity Risk Rating and Risk Measurement-Analysis Based on Stochastic Flow Ratio Model[J]. Financial Forum, 2013(8): 17-23.In Chinese

[11] Hu Fangqi, Song Qin. Research on Liquidity Risk of China's National Debt Market Based on La-VaR Model[J]. Hainan Finance, 2016(1): 17-22.In Chinese 